\title{
Correction to: A facile approach for the synthesis of spinel zinc ferrite/cellulose as an effective photocatalyst for the degradation of methylene blue in aqueous solution
}

\author{
Khaled Charradi $\cdot$ Zakarya Ahmed $\cdot$ Mohamed A. BenMoussa • \\ Zyed Beji · Ameni Brahmia · Israa Othman • Mohammad Abu Haija • \\ Radhouane Chtourou • Sherif M. A. S. Keshk (1)
}

Published online: 16 February 2022

(C) Springer Nature B.V. 2022

\section{Correction to: Cellulose}

https://doi.org/10.1007/s10570-021-04334-3

In the original publication, the same table was processed as table 2 and table 3 mistakenly. The correct version of Tables 2 and 3 with the correct caption are provided in this correction.

The original article has been corrected.

The original article can be found online at https://doi.org/ 10.1007/s10570-021-04334-3.

K. Charradi · Z. Ahmed · M. A. BenMoussa - Z. Beji ·

R. Chtourou · S. M. A. S. Keshk $(\bowtie)$

Nanomaterials and Systems for Renewable Energy

Laboratory, Research and Technology Center of Energy,

Technopark Borj Cedria, BP 095, Hammam Lif, Tunisia

e-mail: keshksherif@gmail.com

A. Brahmia

Chemistry Department, College of Science, King Khalid

University, Abha 61413, Saudi Arabia

I. Othman · M. A. Haija

Department of Chemistry, Khalifa University of Science

and Technology, Abu Dhabi, United Arab Emirates 
Table 2 Comparison of various kinetic models

\begin{tabular}{lllllll}
\hline Rate equation & \multicolumn{2}{l}{$\mathrm{ZnFe}_{2} \mathrm{O}_{4} /$ cellulose } & \multicolumn{2}{l}{$\begin{array}{l}\mathrm{ZnFe}_{2} \mathrm{O}_{4} / \text { active } \\
\text { cellulose }\end{array}$} \\
\cline { 2 - 3 } & $\mathrm{k}$ & $\mathrm{R}^{2}$ & & & $\mathrm{R}^{2}$ \\
\hline Zero-order & 0.0145 & 0.8539 & & 0.0163 & 0.6295 \\
Pseudo-first order & 0.0104 & 0.9592 & 0.0155 & 0.8185 \\
Pseudo-second order & 0.0085 & 0.9711 & 0.0205 & 0.9744 \\
\hline
\end{tabular}

Publisher's Note Springer Nature remains neutral with regard to jurisdictional claims in published maps and institutional affiliations.
Table 3 Particle size and Zeta potential

\begin{tabular}{lll}
\hline Sample & Particle size $(\mathrm{nm})$ & $\begin{array}{l}\text { Zeta } \\
\text { potential } \\
(\mathrm{mV})\end{array}$ \\
\hline $\mathrm{MB}$ & 10 & -5.01 \\
$\mathrm{ZnFe}_{2} \mathrm{O}_{4}$ & 105 & +21.5 \\
Cellulose & 115 & -18 \\
Active cellulose & 180 & -2.1 \\
Composite & 970 & +19 \\
\hline
\end{tabular}

